УДК 371.013.83:378.1(045)

DOI: 10.37026/2520-6427-2020-102-2-168-171
Іван ЦИМБАЛЮК,

кандидат педагогічних наук, доиент кафедри психології, педагогіки та корекційної освіти Рівненського ОІППО

\title{
ГУМАНІСТИЧНІ ІДЕЇ ВАСИЛЯ СУХОМЛИНСЬКОГО В СИСТЕМІ ПІСЛЯДИПЛОМНӦ̈ ПЕДАГОГІЧНОЇ ОСВІТИ
}

У статті висвітлено змістові засади післядипломної педагогічної освіти та підвищення кваліфрікачії вчителів. Окреслено основні гуманістичні ідеі педагогічної спадшини В. О. Сухомлинського та їх творче застосування в конкретному закладі післядипломної педагогічної освіти.

Ключові слова: гуманізм, гуманістичні ідеї, післядипломна педагогічна освіта, фаховість учителя, В. О. Сухомлинський.

В статье освещены содержательные основы последипломного педагогического образования и повышения квалификации учителей. Определень основные гуманистические идеи педагогического наследия В. А. Сухомлинского и их творческое применение в конкретном заведении последипломного педагогического образования.

Ключевые слова: гуманизм, гуманистические идеи, последипломное педагогическое образование, профессионализм учителя, В. А. Сухомлинский.

The leading task of the system of continuous education is that it must become an effective means of enriching the cultural and educational potential of society for the benefit of man, for the sake of the development of each individual, the achievement of a qualitatively new state of society, the continuous rise and improvement of the social way of life in the present and future.

Creating a system of continuous education as a holistic complex to meet the educational and cognitive needs and needs of people, the generator of formation and enrichment of intellectual, professional and cultural potential of the individual and society to reveal its humanistic essence requires the use of all the wealth of appropriate organizational forms.

The organizational structure of the system of continuous education is an orthogonal network, which is formed by the trajectories of gradual, general, professional, and functional development of the individual, on the one hand, and the combination of level educational elements, structures, on the other. At the same time, both generally oriented, and professionally, functionally directed components of the educational system are divided into basic, parallel, and additional. Their differentiation is based on the typologization of ideal, cognitive needs of the individual, the possibilities and conditions of their satisfaction.
The basic humanistic ideas of $V$. Sukhomlynsky's pedagogical heritage are covered. Their creative application in the content of postgraduate teacher education of teachers is offered. Based on the analysis of the process of postgraduate pedagogical education institutions, it is indicated that it uses and develops a wide range of pedagogical ideas substantiated by V. Sukhomlynsky.

Key words: V. Sukhomlynsky, humanism, humanistic ideas, postgraduate education.

Постановка проблеми. Радикальні зміни у змісті та характері праці на основі науково-технічного процесу та нових економічних і політичних факторів, що визначають суспільний розвиток нашої держави, потребують педагогічного осмислення та науково-методичного обгрунтування відповідних форм і методів підвищення кваліфікації на основі гуманістичного підходу до післядипломної педагогічної освіти та вдосконалення фаховості вчителя.

Складний процес духовного відродження нашого суспільства зумовлює глибокі якісні зміни і в методологічному обгрунтуванні концепцій педагогічної та післядипломної педагогічної освіти, що покликані реалізувати стратегію розвитку педагогіки в нових історичних обставинах. Відповідно до цього загострилася потреба в цілісному педагогічному аналізі теорії та практики підвищення кваліфікації вчителів, суттєвим компонентом якого є узагальнені та систематизовані у своєму історичному розвитку наукові знання про закономірності вдосконалення фаховості педагогічних кадрів сучасних закладів освіти.

Система післядипломної педагогічної освіти $\epsilon$ невід'ємною ланкою у структурі освіти, адже суттєво впливає на результат учительської праці. Зважаючи на це, значно актуалізується потреба наукового дослідження трансформації змісту, методів і форм системи післядипломної педагогічної освіти, іiї модельної переорієнтації [8, с. 38].

Етапи оновлення суспільства завжди глибоко впливають на перебудову світогляду і психології людей, духовне життя в цілому. Докорінні зміни, що відбуваються сьогодні в нашій країні, висунули низку вимог до вдосконалення фахової підготовки кадрів та переформатування післядипломної педагогічної освіти. Тому об'єктивна необхідність удосконалення процесу підвищення кваліфікації педагогічних кадрів та фахового розвитку вчителів $є$ соціально зумовленим фактором їх ефективної педагогічної діяльності. 
Для правильного розуміння й вирішення сучасних проблем підвищення кваліфікації вчителів важливе значення має вивчення генези й тенденцій розвитку системи післядипломної освіти, наявних в історії педагогіки, з урахуванням внеску видатних педагогів та вироблення ставлення до них у сучасних умовах.

Таким чином, назріла необхідність подальшого глибокого вивчення якщо не всіх, то хоча б основних аспектів педагогічної діяльності сучасного вчителя 3 метою розробки наукового забезпечення теорії й практики підвищення його кваліфікації на засадах гуманізму та розуміння вчителями особистого внеску в розвиток освіти.

Аналіз наукових досліджень і публікацій. У педагогічній і психологічній науках окреслене нами питання досліджувалося з різних сторін. Так, соціально-педагогічні проблеми адаптації теоретичного i практичного використання педагогічної спадщини В. Сухомлинського досліджено в наукових працях М. Антонця, I. Беха, М. Богуславського, В. Бондаря, М. Вашуленка, С. Гончаренка, І. Зязюна, В. Кременя, Н. Ничкало, О. Савченко, О. Сухомлинської, М. Ярмаченка та ін.

Проблему виховання моральних цінностей у педагогічній системі видатного педагога висвітлювали Л. Бондар, М. Сметанський, В. Ликов та ін. О. Савченко та О. Сухомлинська досліджували створення такої педагогічної системи, в якій головним завданням є виховання толерантності, завбачаючи в цьому виховний потенціал сучасної освіти, а Т. Поніманська розглядала проблему виховання як гуманістичну взаємодію в педагогічній спадщині педагога-новатора.

Ідеї розвивального навчання молодших школярів у педагогічній спадщині В. О. Сухомлинського розкрито дослідницею О. Замашкіною, а окремі аспекти екології дитинства, виокремлені В. Сухомлинським, висвітлено О. Савченко.

Проблема виховання гуманної особистості представлена у працях таких видатних учених, як Ш. Амонашвілі, С. Гончаренко, І. Бех, І. Зязюн, Ю. Мальований та ін., зокрема чільне місце займає ідея гуманізму, людяності й доброчинності в педагогічній спадщині В. Сухомлинського.

Однак, незважаючи на представлену вище низку праць, варто зауважити, що узагальнення результатів вивчення педагогічної, психологічної, історичної, філософської та іншої літератури дає змогу виявити недостатню увагу до здійснення наукових досліджень гуманістичних ідей В. Сухомлинського в педагогіці, адже і сьогодні, на початку XXI століття, вони залишаються актуальними в питанні фахового вдосконалення вчителів у системі післядипломної педагогічної освіти. Саме це й спонукало нас до написання означеної статті.

Мета статті - здійснити контентний аналіз основних гуманістичних ідей педагогічної спадщини В. Сухомлинського як основи фахового вдосконалення вчителів у системі післядипломної педагогічної освіти.

Зважаючи на мету дослідження, можемо сформулювати його завдання, що полягає у вивченні особливостей змісту і процесу вдосконалення вчительської фаховості, де результативно використовують $\mathrm{i}$ розвивають широкий спектр гуманістичних ідей, педагогічно обгрунтованих В. Сухомлинським.
Як зазначалося вище, певний негативний вплив на стан підвищення кваліфікації післядипломної педагогічної освіти спричиняє недостатня наукова досліджуваність проблем вибору змісту післядипломної педагогічної освіти та фахового вдосконалення вчителів, передусім їхніх гуманістичних засад. У зв'язку з цим особливу увагу хочемо приділити систематизації ідей творчої спадщини В. Сухомлинського відповідно до гуманістичної спрямованості системи післядипломної педагогічної освіти та фахового вдосконалення вчителів.

Виклад основного матеріалу. Педагогічні колективи у змісті та процесі вивищення вчительської фаховості результативно використовують і розвивають низку педагогічних ідей, обгрунтованих В. Сухомлинським, головними серед яких уважаємо ідеї:

- гуманізації шкільного життя, що грунтується на розробленій педагогом концепції філософії дитячого щастя;

- гармонізації взаємодії всіх учасників навчально-виховного процесу: педагогів, учнів, батьків, громадськості;

- індивідуалізації навчання, розвитку здібностей і обдарувань вихованців, пам'яті, мислення, творчості, фантазії (уроків мислення, подорожей до джерел думки і слова, уроків творчості, казок школи під блакитним небом, казок вечірніх сутінків, свят казки, книги, рідної мови, щорічного видання рукописних журналів із творчими роботами педагогів та учнів);

- збагачення навчального середовища завдяки природі, праці колективу з перетворення шкільної садиби в оазу краси і пізнання світу, джерело збагачення життєвого досвіду;

- громадянського виховання, зокрема любові до України, громадянськості, ставлення до людей i обов'язок перед ними; ставлення до батьків, рідних, близьких; розуміння життя, добра і зла в ньому; виховання моральних якостей; дружба, любов, сім'я; ставлення до краси в природі і суспільстві;

- утвердження в культу здоров'я і здорового способу життя школярів [8, с. 223].

На основі проведеного нами впродовж 2016 2019 років вивчення змісту фахового вдосконалення вчителів у системі післядипломної педагогічної освіти у Рівненському ОІППО системно проаналізуємо та схарактеризуємо деякі гуманістичні ідеї педагогічної спадщини В. Сухомлинського, які використовуються викладачами кафедри педагогіки, психології та корекційної освіти на заняттях із курсантами.

Ідея гуманізму в педагогічній праці вчителя. Гуманізація освіти нерозривно пов'язана зі змінами уявлень про сутність педагогічного впливу й роль педагога в навчально-виховній взаємодії [5, с. 22]. Діяльність учителя, його проблеми, культура спілкування $з$ дітьми, педагогічна майстерність, духовність, підготовка вчителів у закладах вищої освіти тощо є основними концентрами творчої спадщини видатного педагога. Ці та інші ідеї гуманізму Василь Олександрович висвітлив у праці «Сто порад учителеві» [5].

Учитель, на думку видатного педагога, який не вміє мисленнєво проникати в глибину фактів, причинно-наслідкових зв'язків між ними, неминуче перетворюється на ремісника. Він намагався, щоб кожен педагог був не просто «споживачем» педагогічних звань, а дослідником, раціоналізатором [6, с. 453]. 
Учений-практик значну увагу приділяв розвитку педагогічної культури, що охоплює: розвиток мовлення вчителя, етику та естетику педагогічної діяльності, дидактичні знання та вміння. Педагогічна культура вимірюється рівнем педагогічної майстерності, суть якої - «знайти, помітити, а іноді й створити психологічну ситуацію, що збудила б емоційне ставлення до явищ навколишнього світу» [6, с. 454].

Чільне місце у своїх працях В. О. Сухомлинський відводить ролі вчителя-професіонала, взірця для наслідування: «Учитель - це не тільки той, хто передає учням знання та вміння. Це передусім той, у кого дитина, як у батька і матері, вчиться жити» [1, с. 567].

Особистість учителя Василь Олександрович розглядав як наріжний камінь навчання та виховання, а його професійну і педагогічну майстерність пов'язував із рівнем психологічної культури, психолого-педагогічних знань, розмаїттям засобів естетико-психологічного впливу на учнів. Він стверджував, що вчитель для вихованців може бути одночасно і другом, і наставником. «Ставлення вихованців до особи свого вихователя можна охарактеризувати так: особа вихователя приваблює, захоплює, надихає вихованців цілісністю, красою ідейно-життєвих поглядів, морально-етичних засад. Якщо ви хочете бути могутньою силою, що впливає на колектив, будьте для своїх вихованців, за висловом Тараса Шевченка, апостолом правди і науки, совістю народу» [8, с. 591].

Ідея гуманізму у виховному процесі. Василь Сухомлинський був переконаним прибічником та ідейним пропагандистом гуманістичної педагогіки. Він переконував, що «...виховання гуманізму й людяності повинно стати одним із завдань діяльності школи i вчителя. Вони мають виявлятися в таких якостях і рисах особистості, як талант доброти, потреба в служінні людям - радість самовіддачі» [7, с. 362].

Завданням педагога-вихователя, крім усього іншого, є прищеплення дітям засад людинолюбства. У розвитку педагогічної майстерності наставника саме гуманізм відіграє одну з домінуючих конструктивних ролей. У зв'язку з цим В. Сухомлинський зазначав, що справжній вихователь турбується про те, щоб між його вихованцями існували тонкі емоційні відносини: «Дуже тонке, складне і нелегке в моральному вихованні - це добитися того, щоб кожний вихованець робив добро, приносив радість товаришеві, щоб у цій душевній творчості народжувалася потреба в людині - щира, глибока прихильність учнів один до одного. Навчити робити добро людині - в цьому частина педагогічної майстерності» [7, с. 552].

Позбавлений можливостей відстоювати свою позицію в педагогічній пресі через відмову друкувати статті в умовах цькування Василь Олександрович продовжує розвивати свої ідеї в таких загальновідомих творах, як «Серце віддаю дітям (1969), «Павлиська середня школа» (1969), «Народження громадянина» (1970).

Основні гуманістичні ідеї, які розвинув В. Сухомлинський у своїх працях, і сьогодні є засадничими для методології розвитку професіоналізму вчителя у системі післядипломної педагогічної освіти, а саме:

- любов до дитини, пройнята турботою до ііі блага;

- розвиток творчих сил кожної окремої особистості в умовах колективної співдружності на основі етико-естетичних цінностей, інтересів, потреб, який спрямований у кінцевому підсумку на творчу сумісну працю;
- культ природи як найважливіший засіб виховання почуття прекрасного і гармонії у ставленні до людини і природи;

- розробка демократичних засобів і педагогічних методів навчання й виховання (повага, заохочення, опора на позитивне, моральне покарання, моральні права, земне щастя);

- звернення до внутрішнього світу дитини, опора на іiі сили, внутрішні потенції, підтримка і розвиток того здорового, що є в кожній особистості;

- розвиток ідеї «радості пізнання», тобто емоційне сприйняття процесу навчання та виховання на основі гуманного ставлення до дитини та їі гідності;

- демократизація структури управління навчально-виховним процесом у школі (психологічний і педагогічний семінари, школа для батьків тощо) $[8$, c. $384-385]$.

Ідея вдосконалення змісту післядипломної педагогічної освіти на основі вивчення педагогічних ideй ma досвіду. Складовою інноваційного процесу післядипломної педагогічної освіти є вивчення та впровадження педагогічного досвіду як системи педагогічних знань, умінь і навичок, способів здійснення творчої педагогічної діяльності. «Якщо вчитель не навчився аналізувати факти і створювати педагогічні явища, - зауважував Василь Олександрович, - то справи, що повторюються рік у рік, здаються йому нудними, одноманітними, він втрачає інтерес до власної роботи. А якщо нема інтересу в учителя, то й для дітей навчання стає нудним. Суть педагогічного досвіду в тому й полягає, що перед учителем кожного року відкривається щось нове, і в прагненні осягнути нове розкриваються його творчі сили» $[5$, с. 473$]$.

Ідея гармонізації. Власною педагогічною діяльністю, унікальним педагогічним експериментом у Павлиській школі В. Сухомлинський переконливо довів, що школа як соціальний інститут спроможна повноцінно виконувати всі свої функції за умови тісної співпраці із соціальним оточенням як відкрита виховна система. «У школі, - зазначав Василь Олександрович, - навчають не тільки читати, писати, рахувати, мислити, пізнавати світ, багатства науки й мистецтва. У школі учать жити» [4, с. 337]. Широкі соціальні зв'язки були спрямовані на особистісний розвиток і виховання кожної дитини, зміцнення іiі фізичного, морального, психічного здоров'я, педагогічну підтримку та допомогу сім’ї. Павлиська школа сприяла поширенню нових знань, педагогічному просвітництву, підвищенню культурного рівня середовища. До шкільного життя постійно залучалися місцеві жителі, батьки. Завдяки використанню краєзнавчого матеріалу уроки стали різноманітними й цікавими. Новаторські здобутки В. Сухомлинського - це і школа радості, і школа під блакитним небом, і уроки мислення серед природи, і бесіди з людинознавства, Батьківська школа, психолого-педагогічний семінар, свято Матері, упорядкування «Золотої хрестоматії дитинства», літературні мініатюри для дитячого читання тощо. У педагогічній системі вченого органічно поєдналися народні звичаї, класична педагогіка та власні новаторські творчі знахідки.

Висновки. Гуманістична виховна система видатного українського педагога В. Сухомлинського є однією 3 найвідоміших у світі. Учений-гуманіст, який понад 20 років керував Павлиською школою, зробив величезний внесок у розвиток гуманістичної вітчизняної педагогіки, залишивши нам у спадок глибоку віру в можливість успішного виховання дитини. 
Творча спадщина видатного педагога сьогодні - це не просто сторінка в історії вітчизняної педагогіки, а насамперед творче надбання, варте впровадження у процес нової української школи. Саме гуманістична педагогіка великого людинолюбця вкрай необхідна українським освітянам для творення нової зростаючої особистості. Означені видатним педагогом ще у XX столітті гуманістичні ідеї не втратили своєї актуальності й на сучасному етапі розвитку освіти в Україні. Особливе значення має їх творче втілення в післядипломній педагогічній освіті та в процесі підвищення кваліфікації вчителів.

Перспективи подальших наших досліджень у цьому напрямі вбачаємо у вивченні методичних проблем творчого застосування у змісті та процесі післядипломної педагогічної освіти педагогів гуманістичних ідей педагогічної спадщини В. Сухомлинського.

\section{СПИСОК ВИКОРИСТАНОЇ ЛІТЕРАТУРИ}

1. Антонець М. Я. Славетний український педагог-гуманіст / М. Антонець // Педагогіка і психологія.2003. - № 2. - С. 36-44.

2. Десятов Т. М. Філософія неперервної освіти та освіти дорослих / Т. М. Десятов. ҐURL: http://lib.iitta. gov.ua/6030/1/\%D0\%94\%D0\%B5\%D1\%81\%D1\%8F\%
D1\%82\%D0\%BE\%D0\%B2 \%D0\%A2.\%D0\%9C..pdf (дата звернення: 15.02.2020).

3. Мотрич В. Гуманістичні ідеї В. О. Сухомлинського та їх творче впровадження у навчально-виховний процес спеціальної школи-інтернату. URL: file:///C:/Us ers $/ \%$ D0 $\% 9$ B $\%$ D0 $\%$ B $5 \%$ D $1 \% 81 \%$ D $1 \% 96 \%$ D $1 \% 87 \%$ D

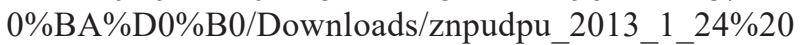
(1).pdf (дата звернення: 10.02.2020).

4. Сухомлинський В. О. Сто порад учителю: вибрані твори : в 5 т. / В. О. Сухомлинський. - К. : Радянська школа, 1976. - Т. 2. - С. 419-654.

5. Сухомлинський В. О. Розмова 3 молодим директором школи: вибрані твори : в 5 т. / В. О. Сухомлинський. - К. : Рад. школа, 1977. - Т. 4. - 639 с.

6. Сухомлинський В. О. Роль особи вчителя в духовному житті колективу та особистості: вибрані твори : в 5 т. / В. О. Сухомлинський. - К. : Рад. школа, 1977. - Т. 1. -654 с.

7. Сухомлинський В. О. Серце віддаю дітям: вибрані твори : в 5 т. / В. О. Сухомлинський. - К. : Радянська школа, 1976. - Т. 3. - С. 9-279.

8. Цимбалюк I. М. Теоретичні та методичні засади підвищення кваліфікації керівних кадрів професійно-технічної освіти : монографія / I. М. Цимбалюк. - Рівне : Каліграф, 2009. - 485 с.

Дата надходження до редакиї: 07.04.2020 p. 